\title{
Alberico Gentili's De iure belli: An absolutist's attempt to reconcile the jus gentium and the reason of state tradition
}

Abstract: Based on a detailed analysis of Gentili's use of sources in De iure belli, this article argues that Gentili's famous treatise on the laws of war is an incongruous attempt at reconciling an absolutist conception of sovereignty and a strong penchant for reason of state principles with an enduring commitment to the language of natural law and to its centrality in ordering relations between sovereigns.

Keywords: Gentili; reason of state; laws of war; Bodin; absolutism; sovereignty; natural law

\section{Introduction}

Recent years have witnessed a renewed interest in the writings of Alberico Gentili (1552-1608), particularly his works on war, ${ }^{1}$ and a surge in debates over how to interpret the sixteenth century Italian émigré's ideas. Ever since Richard Tuck identified Gentili with a humanist tradition deeply opposed to the ideas of the scholastics in The Rights of War and Peace, Gentili's writings on the laws of war, and especially his masterpiece on the subject, De iure belli (DIB), have been scrutinized in order to determine where exactly Gentili stood amidst the conflicting ideologies and modes of thinking of his time. In addition, various claims have been put forward to explain the specificity of DIB, both in the specialized literature on early modern legal debates and within

\footnotetext{
1 The most notable contributions include Benedict Kingsbury and Benjamin Straumann, eds., The Roman Foundations of the Law of Nations: Alberico Gentili and the Justice of Empire (Oxford: Oxford University Press, 2010); Alberico Gentili, The Wars of the Romans: A Critical Edition and Translation of De Armis Romanis, ed. Benedict Kingsbury and Benjamin Straumann, trans. David A. Lupher (Oxford: Oxford University Press, 2011); and Alberico Gentili, Il diritto di guerra (de iure belli libri III, 1598), trans. P. Nencini, ed. G Marchetto and C. Zendri, with an introduction by D. Quaglioni (Milano: AGiuffrè, 2008).
} 
broader histories of international law and of the laws of war. This new surge of interest comes amidst a long tradition of treating Gentili's DIB as a pivotal text in the history of international law, notably for its 'secular' underpinnings and for its 'modern' conception of the laws of war. ${ }^{2}$

The purpose of this article is to clarify some of these disagreements by closely examining Gentili's use of sources in DIB. More specifically, through this focus on sources, the article seeks to resituate Gentili's DIB beyond the immediate legal debates that have conventionally framed its analysis, and to place the text within the broader political thought of the period. Gentili's text, the article claims, is particularly noteworthy in its attempt to straddle the legal and political debates of its epoch, looking beyond legal sources and turning to various contemporary political writers in what was quite a remarkable move at the time. His attempt to bridge what has been identified within international political thought as the two broad 'languages' of the period - the legal and the political—is an aspect of his work that has not been sufficiently examined, despite its potential for shedding a new light on the dynamics that underpinned the development of international law at the time. ${ }^{3}$

\footnotetext{
${ }^{2}$ This is particularly obvious in the main textbooks on the history of international law (Grewe, Schmitt, Nussbaum). Gentili's modernity in his approach to the law of war, particularly when compared with Grotius, has also been emphasized in the more specialized literature, including by Haggenmacher, who notes that DIB 'often seems closer, if not to the 1899/1907 Hague Rules of Land Warfare, at least to the spirit of eighteenth-century warfare as reflected by authors like Moser or Vattel, than is the Grotian system, however elaborate, coherent, and profound it may be,' though he does point to the inherent anachronism involved in this type of assessment. Peter Haggenmacher, "Grotius and Gentili: A Reassessment of Thomas E. Holland's Inaugural Lecture", in Hedley Bull, Benedict Kingsbury, and Adam Roberts (eds.), Hugo Grotius and International Relations (Oxford: Oxford University Press, 1992), 168 and 173.

${ }^{3}$ In presupposing a distinction between the two, I am speaking exclusively here of the debates concerning intersovereign relations. At the inter-sovereign level, the initial separation between, on the one hand, a 'political' language centered around the concepts of 'reason of state' and the 'balance of power', and, on the other hand, the 'legal or jurisprudential' language centered on old notions of 'natural law' and 'law of nations' now repackaged to conceptualize the 'rights' of sovereigns and people has been outlined particularly sharply by Keene (Edward Keene, International Political Thought: A Historical Introduction (Cambridge: Polity Press, 2005), 98-133). The broader claim about the existence of different 'languages' of early modern international political thought is drawn from Pagden (Anthony Pagden (ed.), The Languages of Political Theory in Early Modern Europe (Cambridge: Cambridge University Press, 1987)). A convincing case can be made for why the boundaries between these areas was much more porous at the domestic level (see for instance Kelly, John M., A Short History of Western Legal Theory (Oxford: Clarendon Press, 1992), xvi).
} 
This is not to say, of course, that no attention has been paid to the more political aspects of DIB, and to its affinity, as a legal text, with certain strands of political thought. Much of the current debate about whether DIB — and Gentili more broadly — should be placed within the humanist category, can in a way be understood as a disagreement over Gentili's political leanings. Yet, humanism was only one facet of the political thought of the period, and its age-old premises were being increasingly overshadowed by the rise of new modes of political thinkingparticularly the concept of raison d'état - that eventually came to characterize the emerging era. This article pays closer attention to the latter, emphasizing DIB's surprising and generally underappreciated affinities with these ideas. ${ }^{4}$ It builds upon existing works that highlight Bodin's momentous influence on Gentili, and expands this analysis by taking stock of Gentili's equally striking reliance on writers from the emerging reason of state tradition, thus articulating Gentili's use of Bodin through his broader engagement with the burgeoning intellectual currents of his time. In doing so, the article pushes back against the '(standard) argument' that 'international law arose with modern statehood as a position and a craft that was opposed to the raison d'état. ${ }^{, 5}$ If Gentili's famous treatise on the law of war is by any means an indicator of how international law initially developed, raison d'état certainly needs to be placed back at the heart of how we study the history of international law.

Having set out the context within which Gentili's use of sources can be interpreted, I outline the most striking influences on his text, and explain why these are key to understanding what was so particular about the Italian jurist's famous treatise on the laws of war at the time.

\footnotetext{
${ }^{4}$ It is worth noting that in his seminal work on Grotius and his forerunners, Haggenmacher mentions Bodin and his influence only briefly, he cites Machiavelli just once (to note a 'curious coincidence' between his thinking and that of Grotius regarding what the sovereign is entitled to do with his or her state, n. 898), and he never mentions Guicciardini. Peter Haggenmacher, Grotius et la doctrine de la guerre juste (Genève: Graduate Institute Publications, 1983).

${ }^{5}$ Martti Koskenniemi, 'International Law and Raison D'état: Rethinking the Prehistory of International Law', in The Roman Foundations of the Law of Nations, ed. Benedict Kingsbury and Benjamin Straumann (Oxford: Oxford University Press, 2010), 298.
} 
Ultimately, I argue that one of the most important reasons why Gentili's DIB stood out was that it was the work of an absolutist who tried to base a theory of the laws of war on what was at the time a groundbreaking and controversial conception of sovereignty. In doing so, Gentili's primary concern was to reconcile Bodin's concept of sovereignty, the teaching of the reason of state writers, and his own commitment to ensuring law would continue to matter in regulating external relations between sovereign polities. Gentili's absolutism, i.e. his commitment to a radical understanding of sovereignty that granted almost unlimited powers to the ruler, has of course been a hotly debated matter, not least because Gentili's stance evolved over the course of his career, and because branding him an absolutist was a very convenient way for Catholic critics to undermine the Protestant jurist's work when it was forcefully revived in the nineteenth century. ${ }^{6}$ DIB, in particular, is not as stark in its absolutist claims as some of Gentili's later writings, nor as systematically coherent in its positions, thus leaving some room for debate. I address these points explicitly in the second part of the article.

To this purpose, I first outline some elements of clarification for how we may understand Gentili's work and particularly his De iure belli, highlighting some of the major debates concerning Gentili's writings. Second, I point to the well-established influence of Bodin on Gentili, particularly in terms of his absolutist conception of sovereignty, but conclude that while Gentili fully embraced Bodin's absolutist position, he had to look elsewhere in order to adapt Bodin's ideas to relations between early modern states. Third, I examine the reason of state writers to which Gentili turned in attempting to develop a framework for inter-sovereign relations. Fourth and finally, I argue that the main challenge Gentili faced was adapting the ideas of these writers, who saw little use for law in facilitating and stabilizing external relations

\footnotetext{
${ }^{6}$ See, for instance, Gustave Rolin-Jaequemyns, 'Quelques mots sur les hommages projetés à la mémoire de Grotius et d'Albéric Gentil, et sur les dernières publications y relatives', Revue de droit international et de législation comparée, tome VIII (1875), 694.
} 
between early modern states, to his commitment to placing law at the center of this endeavor. In other words, Gentili took what was then the fairly counter-intuitive step of trying to incorporate the increasingly popular concepts of raison d'état and balance of power into a legal framework for inter-sovereign relations.

Before I begin, a bibliographical note: De iure belli libri tres was first published in 1598, as an expanded version of Gentili's earlier lectures De iure belli commentationes tres (1588/89). A few reeditions then appeared, in 1604, 1612, 1770, and in 1877 during the nineteenth century revival of Gentili's work. Finally, in 1933 the treatise was reedited in what is now the most commonly used edition, which contains both a photographic reproduction of the 1612 edition and an English translation of the original Latin. In the analysis that follows, I have referred to this 1933 edition, which allows one to consult the 1612 text in parallel with its English translation. Importantly, the marginalia in the 1933 English translation mirrors exactly that of the 1612 Latin original, and the marginalia of the 1612 version is identical to that of the original 1598 edition. $^{7}$

\section{Reading Gentili's DIB: some elements of clarification}

For all the celebrations of Gentili as a great founder of international law, there is a certain amount of confusion and mystery that shrouds his work. Often his positions across his different publications seem inconsistent, making it difficult to understand where he stood and how exactly his different writings relate to each other. Three main reasons for this confusion stand out: first, while Gentili spent his first Oxonian decade (1581-1590) teaching and writing the treatises that

\footnotetext{
${ }^{7}$ I have verified this by comparing the 1612 photographic reproduction to John Selden's copy of the 1598 original, which is available at the Bodleain Library under the filing number $8^{\circ} \mathrm{G}$.6.Jur.Seld.
} 
established him as a leading jurist of his day, ${ }^{8}$ the later part of his career (1590-1608) was more fully dedicated to practice and consequently, he wrote numerous opinions that depended primarily on his clients' interests and thus often contradicted each other. Second, Gentili evolved significantly during his career, from a staunch Bartolist following his training in Perugia to what Randall Lesaffer has termed a 'moderate humanist' over the course of his time in England, embracing 'a via media between Bartolism and humanism'. 9 Third, and relatedly, the term 'humanism' has come to encompass a number of meanings, and in the longstanding debate over whether or not Gentili was indeed a humanist, it is not always clear whether the humanism in question is of a civic, rhetorical, or legal kind. In this section, I will thus outline four crucial elements for situating the work of Gentili—-specifically his DIB — and navigating this somewhat muddled contextual landscape.

First of all, Gentili wrote at a time of nothing short of a methodological revolution in international law and history, ${ }^{10}$ pitting the traditional ideas of Bartolists (the 'mos italicus') against the sensational innovations of the initially Bourges-based legal humanists (the 'mos gallicus' $^{\prime},{ }^{11}$ and his position within that debate evolved significant throughout his career. The

\footnotetext{
${ }^{8}$ In the words of K. R. Simmonds, 'there can be little doubt that at his death in 1608 much of his reputation as a scholar and publicist rested upon the work of his earlier career in Oxford'. K. R. Simmonds, 'The Gentili Manuscripts', Zeitschrift Der Savigny-Stiftung Für Rechtsgeschichte. Romanistische Abteilung 76, no. 1 (1959): 546.

${ }^{9}$ For brief statements, see Alain Wijffels, 'From Perugia to Oxford: Past and Present of Political Paradigms', in Alberico Gentili: La Traduzione Giuridica Perugina E La Fondazione Del Diritto Internazionale, ed. Ferdinando Treggiari (Perugia: Università degli Studi di Perugia, 2008), 59-61; Randall Lesaffer, 'Alberico Gentili's Ius Post Bellum and Early Modern Peace Treaties', in The Roman Foundations of the Law of Nations, ed. Benedict Kingsbury and Benjamin Straumann (Oxford: Oxford University Press, 2010), 216; Simmonds, 'The Gentili Manuscripts' 1959 (n. 10), 546-549. For longer analyses, see Giovanni Minnucci, Alberico Gentili tra mos italicus e mos gallicus: l'inedito commentario ad legem Juliam de adulteriis, Archivio per la storia del diritto medioevale e moderno ; 6 (Bologna: Monduzzi Editore, 2002); Giovanni Minnucci, 'Per Una Rilettura Del Metodo Gentiliano', in Alberico Gentili: La Traduzione Giuridica Perugina E La Fondazione Del Diritto Internazionale, ed. Ferdinando Treggiari (Perugia: Università degli Studi di Perugia, 2008).

${ }^{10}$ Julian H. Franklin, Jean Bodin and the Sixteenth-Century Revolution in the Methodology of Law and History (New York: Columbia University Press, 1963).

${ }^{11}$ Though as Haggenmacher notes, the relationship of the mos gallicus to the mos italicus should be characterized as an effort to broaden and transform rather than as a move towards clear rupture and a complete rejection of tradition.
} 
debate was essentially one over how best to understand, interpret, and use Roman law, the vast majority of which was compiled in what became known as the Corpus iuris civilis. Throughout the Middle Ages, the assumption of the Bartolists (mos italicus) had been that the Corpus iuris was a perfect system of jurisprudence, and the resulting approach had been to focus on exegesis of the Roman Law and to creatively adapt Roman concepts to the medieval world. The scholastic method, on which this was based, entailed virtually pure logical analysis with very little historical perspective. The French legal humanists (mos gallicus) started out seeking to improve Roman jurisprudence by restoring its original meaning, which sometimes had been lost through misinterpretation, erroneous translations, or copying errors. Their initial endeavor, however, developed into a full-blown critique of Roman law when they realized that their attempt to discover the unifying logical underpinnings of the Corpus iuris was bound to fail because these were in fact, they concluded, inexistent. Roman law, they explained, was riddled with inconsistencies and logical incoherence, and, perhaps even more importantly, it was based on concepts that were developed in the particular historical context of Rome and that were sometimes completely at odds with the realities of their own world.

As a result, these legal humanists advocated taking a much more critical stance towards Roman law and particularly towards the writings of great medieval authorities on the matter (such as Bartolus and Baldus), as well as looking beyond Roman law to create a better system of jurisprudence. This led to a renewed focus on domestic legal custom, but even more importantly, it led to a crucial turn towards the use of 'universal history' in the reconstruction of a juristic science. ${ }^{12}$ In other words, legal humanists_-and particularly Jean Bodin on this specific matterhoped to remedy the deficiencies in the Roman legal system by turning to universal history.

In his writings on war, Alciatus, one of the most famous proponents of the mos gallicus, is clearly indebted to both the humanists and to the Bartolists. Haggenmacher, Grotius et la doctrine de la guerre juste (n. 4), 47-48.

12 Ibid. 
Bodin puts it most clearly himself in République: the sole way to build a truly universal juristic science, he explained, was to compare 'all the laws of all, or the most famous, states, and to select the best variety'. ${ }^{13}$ The legal humanists thus turned their attention away from the medieval commentators and towards a vast web of sources, with a particular emphasis on the work of historians.

Gentili was trained at Perugia as a Bartolist of the purest kind, and when he first arrived in Oxford, his first publication was a famous attack on legal humanism, De iuris interpretibus (1582), which categorically condemned the arguments of the great three-Budaeus, Alciatus, Zasius - and their followers. In the following two years, he published another attack on legal humanism: his polemical collection of letters and lectures entitled Lectionum et epistolarum quae ad ius civile pertinent (1583-4). However, by the time he wrote the first draft of DIB for his 1589 lectures on the laws of war, he had gradually moved away from this complete rejection of the mos gallicus and, while he remained faithful to his Bartolist training, he clearly embraced many of the tropes of legal humanism, most notably in his use of sources. ${ }^{14}$ Indeed, in addition to citing the Corpus iuris civilis and the numerous commentaries on it-particularly those of Baldus - Gentili relies extensively on classical philosophers and rhetoricians (especially Cicero), classical historians (especially Livy), classical poets (especially Virgil), ${ }^{15}$ and contemporary historians (such as Paolo Giovio and Paolo Emilio). More tellingly still, he cites Alciatus, one of the foremost legal humanists, whom he calls a 'great jurist', ${ }^{16} 231$ times in DIB, second only to the main Bartolist authority, Baldus, whom he cites 315 times, and the Corpus iuris itself, which

\footnotetext{
13 Jean Bodin, On Sovereignty: Four Chapters from the Six Books of the Commonwealth, (Cambridge: Cambridge University Press, 1992), xvi.

${ }^{14}$ A helpful summary of the different ways in which the influence of humanism can be felt in Gentili's work can be found in Lesaffer, 'Alberico Gentili's Ius Post Bellum and Early Modern Peace Treaties' 2010 (n. 11 ), 218.

${ }^{15}$ For a detailed discussion of Gentili's reliance on poetry, see Christopher Warren, 'Gentili, the Poets, and the Laws of War', in The Roman Foundations of the Law of Nations: Alberico Gentili and the Justice of Empire, ed. Benedict Kingsbury and Benjamin Straumann (Oxford: Oxford University Press, 2010), 146-62.

${ }^{16}$ Ibid., 149. Gentili also calls him 'the wise Alciati' (DIB, Book I, §17).
} 
he cites 465 times. $^{17}$ Furthermore, while Gentili does regularly cite the Bible (with an overwhelming preference for the Old Testament), it is, with 193 citations, an important source but by no means as central as in the work of his more traditional predecessors. Similarly, he only cites Church Fathers (Tertullian, St Ambrose, St Jerome, St Bernard) between twenty and thirty times each, a rather low ratio compared to the wealth of other sources that are cited more frequently (see Figure 1). Thus, while Gentili ultimately never fully adopted the skepticism of the mos gallicus towards the Corpus iuris civilis and its medieval interpreters, the influence of legal humanism can strongly be felt in DIB and clearly had a strong impact on the way Gentili developed his positions. As such, the Gentili of the late 1580s and the 1590s is best understood as a 'moderate humanist' in the legal sense, with one foot still squarely within the Bartolist tradition and the other increasingly anchored within the mos gallicus and the challenges raised by legal humanism.

Secondly, while a number of scholars have questioned the idea of a definite cleavage between Gentili and the School of Salamanca (particularly Vitoria), ${ }^{18}$ is it also far from clear that Gentili's main interlocutors in DIB are in fact the theologians. The now conventional emphasis

\footnotetext{
${ }^{17}$ There is also clear evidence that over his time at Oxford he became friends with Hugo Donellus and François Hotman (both dedicated supporter of Cujas), the latter whom he cites twenty-five times. In fact, Gentili cites Cujas himself thirty times in DIB. On the presence of evidence in the Bodleian manuscripts of Gentili's friendship with Donellus and Hotman, see Simmonds, 'The Gentili Manuscripts' 1959 (n.10), 548.

${ }^{18}$ In the words of Blane and Kingsbury, '[a]ll three were Christian believers who were engaged in theological debates; Vitoria was a professional theologian influenced by jurists; Gentili and Grotius were theologically-informed jurists'. Alexis Blane and Benedict Kingsbury, 'Punishment and the Ius Post Bellum', in The Roman Foundations of the Law of Nations, ed. Benedict Kingsbury and Benjamin Straumann (Oxford: Oxford University Press, 2010), 246-7. For an insightful account of the similarities between Gentili and the Salamancans on the subject of the treatment of the Ottomans, see Noel Malcolm, 'Alberico Gentili and the Ottomans', in The Roman Foundations of the Law of Nations: Alberico Gentili and the Justice of Empire, ed. Benedict Kingsbury and Benjamin Straumann (Oxford: Oxford University Press, 2010), 127-45. More broadly, Lesaffer and Pagden question Tuck's classic divide between humanists (which in Tuck's account, supported by Diego Panizza, include Gentili) and scholastics, with Padgen arguing that 'the more one examines the humanist/scholastic or humanist/theologian distinction, the more fuzzy it becomes. Anthony Pagden, 'Gentili, Vitoria, and the Fabrication of a "Natural Law of Nations"', in The Roman Foundations of the Law of Nations, ed. Benedict Kingsbury and Benjamin Straumann (Oxford: Oxford University Press, 2010), 345; Randall Lesaffer, 'The Classical Law of Nations (1500-1800)', in Research Handbook on the Theory and History of International Law, by Alexander Orakhelashvili, Research Handbooks in International Law (Cheltenham: Edward Elgar, 2011), 424-430.
} 
on the humanist/scholastic distinction presupposes that if, as Richard Tuck and Diego Panizza argue, Gentili was indeed a humanist, his main opponents and interlocutors were the theologians of the Second Scholastic, and particularly those of the School of Salamanca. However, the diversity within forms of humanism suggests that different debates may have been at stake, and that Gentili's 'humanist' affinities did not necessarily make engaging the Salamancans his primary interest. In terms of citations, Gentili only cites Covarruvius ${ }^{19}$ (or Covarrubias) twentytwo times, Vitoria seven times, and Soto four times (there is no mention of Molina). By contrast, he cites political writers - who had little interest in arguing with the theologians - such as the Italian historian and statesman Francesco Guicciardini and the French jurist and political philosopher Jean Bodin sixty-three and thirty-nine times respectively. In fact, the influence of Bodin on Gentili and the considerable weight Gentili gave to Bodin and his arguments in DIB are well-documented, ${ }^{20}$ and I will return to this important point later on in the article. For now, this mainly hints towards the fact that Gentili's main motivation in writing DIB may not have been to undermine the arguments of the theologians - who were nonetheless his political rivalsas much as to address the ideas of the French politiques and the Italian ragion di stato writers, who both emphasized the utmost importance of the well-being of the state and were stirring up considerable debates at the time.

As this discussion suggests, the methodological debates that surrounded Gentili make his use of citations deeply revealing. Summing up and expanding on this analysis, the chart below

\footnotetext{
${ }^{19}$ Corravubias was a canon lawyer rather than a theologian, but he was deeply influenced by the School of Salamanca.

${ }^{20}$ Diego Quaglioni, 'The Italian 'Readers' of Bodin, 17th-18th Centuries: The Italian 'Readers' out of Italy-Alberico Gentili (1552-1608)', in The Reception of Bodin, ed. Howell A. Lloyd (Leiden: Brill, 2013), 371-86; Diego Quaglioni, 'Pour une histoire du droit de guerre au début de l'âge moderne. Bodin, Gentili, Grotius', trans. Jean-Louis Fournel, Laboratoire italien. Politique et société, no. 10 (December 31, 2010); Peter Schröder, 'Vitoria, Gentili, Bodin: Sovereignty and the Law of Nations', in The Roman Foundations of the Law of Nations, ed. Benedict Kingsbury and Benjamin Straumann (Oxford: Oxford University Press, 2010), 163-86; Wijffels, 'From Perugia to Oxford' 2008 (n. 11).
} 
gives an overview of the main sources cited by Gentili in DIB, dividing them into broad categories based on their nature. It is worth noting that unlike Grotius, Gentili does not appear to follow a systematic pattern in citing different sources. For instance, while Grotius tends to cite religious authorities on each point, before moving on to non-religious ones - surely an effective way to satisfy different audiences - Gentili's citations simply seem to follow the trajectory of his argument, with what he considers the most relevant authors cited in support of particular points, regardless of their affiliation. Ultimately, although this quantitative collection of data presents certain limits in terms of establishing how Gentili actually engaged with the different sources he invokes, Figure 1 provides an overview of Gentili's universe of citations and constitutes a first set of insights for assessing the impact of various types of sources on Gentili's thought in DIB. I provide a more in depth analysis of his use of certain key sources, particularly Bodin and Guicciardini, later on in the article. ${ }^{21}$

What becomes clear from these charts is that in addition to the sources one would expect to find in the writings of a civil lawyer of this period, educated within the Bartolist tradition and influenced by both rhetorical and legal humanists-namely, the Corpus iuris and various commentaries on it from both legal traditions (Baldus, Alciatus...), scriptural sources (Bible, Church Fathers, canon law, theologians), classical philosophers and rhetoricians (Cicero, Plutarch, Aristotle...) — one key aspect of Gentili's universe of citations stand out as particularly unusual. I am speaking here of his considerable reliance on historians from all ages, and most notably — an uncommon feat at the time amongst jurists—on contemporary historians. Indeed, Gentili relies significantly on classical historians (Livy, Plutarch's biographies, Tacitus, Cassius...) and on other antique historians, especially Jewish and Byzantine ones (Josephus,

\footnotetext{
${ }^{21}$ This type of two-tier quantitative/qualitative approach is not entirely uncommon, see for example Haggenmacher, "Grotius and Gentili: A Reassessment" (n. 2), 146-147.
} 
Procopius, Zonaras), but also on a range of modern historians, particularly historians of Italy, most importantly Paolo Giovo, Francesco Guicciardini, and Paolo Emilio. Additionally, Bodin, who had died just two years before the publication of De iure belli, is one of Gentili's contemporaries who gets the most citations, and as I will explain at greater length in part II, he is in fact discussed extensively throughout the text and has been established as a major influence on DIB through an analysis of Gentili's manuscripts. Moreover, in light of the present discussion on the use of different types of sources, it is worth mentioning that there is indeed a close connection between Gentili's methodological turn to history and his heavy reliance on his French contemporary, a point to which I will return later.

Figure 1: Gentili's main sources, by type

\begin{tabular}{|c|c|c|}
\hline Rank & Source & $\begin{array}{c}\text { Number of } \\
\text { citations }\end{array}$ \\
\hline 1 & Corpus iuris civilis & 465 \\
\hline 2 & Baldus (MI) & 315 \\
\hline 3 & Alciatus (MG) & 231 \\
\hline 4 & Cicero & 200 \\
\hline 5 & Bible & 193 \\
\hline 6 & Livy & 154 \\
\hline 7 & Plutarch & 117 \\
\hline 8 & Cephalus (MI) & 104 \\
\hline 9 & Alexander (MI) & 102 \\
\hline 10 & Augustine & 75 \\
\hline 11 & Decio (MI) & 75 \\
\hline 12 & Corpus iuris canonici & 68 \\
\hline 13 & Aristotle & 66 \\
\hline 14 & Plutarch (biographies) & 66 \\
\hline 15 & Paolo Giovo & 65 \\
\hline 16 & Guicciardini & 63 \\
\hline 17 & Seneca & 60 \\
\hline 18 & Tacitus & 54 \\
\hline & & \\
\hline & & \\
\hline
\end{tabular}




\begin{tabular}{|l|c|c|}
\hline 19 & Cassius & 48 \\
\hline 20 & Decianus (MI) & 48 \\
\hline 21 & Pontanus (MI) & 48 \\
\hline 22 & Plato & 40 \\
\hline 23 & Josephus (Jewish) & 39 \\
\hline 24 & Paolo Emilio & 39 \\
\hline 25 & Bodin & 39 \\
\hline 26 & Philo Judaeus & 37 \\
\hline 27 & Virgil (Roman) & 37 \\
\hline 28 & Procopius (Byzantine) & 37 \\
\hline 29 & Zonaras (Byzantine) & 37 \\
\hline 30 & Jason Maynus (MI) & 37 \\
\hline
\end{tabular}

Table 1: Gentili's main sources, by overall citation ranking

Thirdly, although DIB was published in full in 1598, the fact that Gentili wrote most of the content of DIB at the end of his scholarly period suggests that the positions he defends within DIB stem from a genuine attempt at developing a system of law rather than the sort of interestbased positions found in works such as Hispanicae advocationis, the collection of opinions he wrote while (controversially) defending the Spanish Crown in the final part of his career. His other main work on war, De armis Romanis (DAR), although the second part was only published in 1599 (after his scholarly period), was also written around the same time, with the first part published in 1590 and the full draft ready by 1593. While the interpretation of this second work, and particularly its relationship to DIB, is notoriously arduous, it is clear that Gentili spent a significant amount of his scholarly period reflecting on the laws of war from an academic standpoint, prior to dedicating himself to practice and writing on some of these matters (particularly piracy and privateering) as an advocate in Admiralty Courts. One should thus appreciate the qualitative difference between what Gentili was attempting to do in writing DIB (and DAR) and in later on defending what have been pointed out as contradictory positions 
within the context of his career as a lawyer. Importantly, this does not, however, mean that one should discount all of Gentili's later writings as unreliable or written for exclusively instrumental purposes. Gentili did still write some pieces as a scholar rather than as a practitioner (such as his Regales disputationes tres of 1605), and his work as a lawyer still offers important insights into his thinking. The main point is that while his arguments as an advocate on, most notably, piracy and privateering, sometimes contradict each other (depending on who his client is) and are sometimes at odds with his earlier claims in DIB, these inconsistencies are not necessarily surprising and should be understood in the context of his dual professional identity.

Finally, one of the most important characteristics of Gentili to keep in mind in analyzing DIB is that he is a Roman law expert, or what the English called a 'Civilian'. This feature followed from his training in Italy, and was further accentuated when he took up the position of Regius Professor of Civil Law at the University of Oxford in 1587. International ${ }^{22}$ lawyers were logically Roman law experts, as Roman law provided numerous rules for dealing with international or proto-international issues within the Roman empire, whereas common law was based on the assumption that it applied solely within a domestic context, there being no higher authorities than the domestic ones. Yet, being a civilian in a common law country was a rather peculiar situation, and in fact the Regius Chair had only been founded in the 1540s, along with a similar one at Cambridge. In a common law system, Roman law experts were only relevant within two specific types of courts that applied Roman-based civil law, namely ecclesiastical courts and admiralty courts. The latter in particular were a very important space for international jurists like Gentili, as they dealt directly with international issues, particularly with issues of prize and booty at the heart of which stood perennial questions about how to distinguish pirates

\footnotetext{
${ }^{22}$ Throughout the article, I use the term 'international' as a heuristic device to speak of the realm pertaining to relations between independent sovereign polities. At the time, these relations were obviously 'inter-sovereign' rather than 'international' in the modern sense.
} 
from privateers. For all other matters, the common law ruled, and there was a deep cleavage between common lawyers and their civilian rivals, who were indeed deeply unpopular. In fact, sometime in the late fifteenth or early sixteenth century, civil lawyers had come to form a separate society of their own, called the Doctors' Commons or College of Civilians, where its members could live, work, consult the library, and follow proceedings of the civil law courts. Gentili thus held a peculiar position as Oxford's Regius Professor of Civil Law, and his work could easily have generated suspicion from his contemporaries working within the common law tradition, as we will see later on with regard to his support of James I. Importantly, it may also go some way into explaining why Gentili's work lost much of its clout after his death only to be properly revived two and a half centuries later.

Ultimately, Gentili's near-veneration of Roman law was uncommon even for a Civilian. His great admiration for Rome led him not only to give pride of place to Roman law in DIB, but in fact to equate Roman law with the jus gentium, and to construct the latter as the content of natural law itself. ${ }^{23}$ For Gentili, Roman law constituted the content of both the jus gentium (at the time, roughly interpreted as what we would call the 'positivist' law of nations, though in the twentieth century it has been equated with the specific law of individuals, e.g. human rights) and the jus naturale (natural law), making the jus gentium not only universal but also immutable. Roman law, in the eyes of Gentili, constituted the finest and final achievement of mankind, and provided an eternal legal framework for all. This position was notably different from that of the Romans themselves (and from that of his later rival, Grotius). ${ }^{24}$ Indeed, the Romans considered the jus gentium to be the law regulating the relationships between Romans and non-Romans; they did not construe it as a universal law in the same way as the early modern jurists, and

\footnotetext{
${ }^{23}$ Pagden, 'Gentili, Vitoria, and the Fabrication of a "Natural Law of Nations"' 2010 (n. 20).

${ }^{24}$ Though it would later be taken up by Giambattista Vico with his concept of the 'natural law of nations'.
} 
especially not as Gentili did. In addition to being a Roman law expert, Gentili was thus quite unusual in his conception of Roman law, and it is essential to keep in mind the centrality which Gentili gave it in his system of law in order to understand the particularity of DIB. Most importantly, Roman law generally presupposes an emperor, a supreme authority whose doings nobody can judge. ${ }^{25}$ This underpinned what is perhaps Gentili’s most crucial characteristic, to which I next turn: his absolutism.

\section{Conceptualizing sovereignty: the influence of Bodin}

Gentili expressed his strikingly strong absolutism most famously in 1605, in the first disputation of his Regales disputations tres, entitled De potestate regis absoluta and dedicated to the new Stuart King, James I. In fact, Gentili's three disputations of 1605 have sometimes been called 'the most absolutistic piece of writing that appeared in England in the early seventeenth century', ${ }^{26}$ and Gentili himself 'the theoretical founder of absolutism in England'. ${ }^{27}$ Gentili's absolutism made him stand out as a jurist (particularly in England) and is, I will argue, a fundamental element to understand the specificity of his theory of the laws of war. Gentili's absolutism stemmed from a combination of his admiration of Roman law with the profound

\footnotetext{
${ }^{25}$ Although it is worth noting that the Roman tradition also had a Republican phase, and that medieval glossators and commentators had managed to interpret Roman law as to justify a complex web of overlapping sovereignties that was far removed from any sort of absolutist system.

${ }^{26}$ Brian Levack, 'Law and Ideology: The Civil Law and Theories of Absolutism in Elizabethan and Jacobean England', in The Historical Renaissance: New Essays on Tudor and Stuart Literature and Culture, ed. Heather Dubrow and Richard Strier (Chicago ; London: University of Chicago Press, 1988), 229.

${ }^{27}$ Brian P. Levack, The Civil Lawyers in England, 1603-1641: A Political Study (Oxford: Clarendon Press, 1973), 98. In making this argument, Levack is following Gesina Van der Molen, Alberico Gentili and the Development of International Law, second edition (Leyden: A. W. Sijthoff, 1968), 330-1. However, almost no one, apart from John Cowell (1554-1611) - Gentili's counterpart as the Regius Professor of Civil Law at Cambridge - 'picked up on Gentili's work until it was used to reveal the real kernel of royalist belief in an anonymous parliamentary tract of 1644'. Glenn Burgess, Absolute Monarchy and the Stuart Constitution (New Haven; London: Yale University Press, 1996), 78. For a detailed analysis of the tract, entitled 'Englands Monarchy, or A Conviction and Refutation by the Common law of those False Principles and Insinuating Flatteries of Albericus', see Andrew Sharp, 'Alberico Gentili's Obscure Resurrection as a Royalist in 1644', in Alberico Gentili: L'ordine Internazionale in Un Mondo a Più Civiltà: Atti Del Convegno Decima Giornata Gentiliana (San Ginesio: Milano: Giuffrè, 2002).
} 
influence that Bodin's theory of sovereignty had on him. Yet, Bodin's theory raised as many problems for Gentili as it provided solutions, and Gentili had to search elsewhere to address these issues. In this section, I give an overview of the importance of Bodin's ideas for Gentili before turning, in part III, to the writers he drew from in constructing a system of laws geared towards the interaction of independent sovereign polities.

While the French Bodin $^{28}$ was not an absolutist from the start, as apparent in his Methodus of 1566 (which Gentili does not cite in DIB), by the time he wrote the Six livres de la République in 1576 ('République'), he had-almost unintentionally-come to adopt the absolutist position he would remain famous for. ${ }^{29}$ That being said, it is well-established that what Gentili took away from Bodin's work was an uncompromising embrace of the staunchest absolutism. His position - and the influence of Bodin on this point - is at its clearest in his aforementioned 1605 tract on the Absolute Power of the King (De postesta regis absoluta), in which Gentili defends the absolutist theory that the Stuart King James I-who was likely to have been influenced by Bodin himself ${ }^{30}$ - had put forward in 1598, shortly before his accession to the

\footnotetext{
${ }^{28}$ Jean Bodin was a French jurist who wrote in the context of a tentatively constitutionalist France, operating based on a notion of limited supremacy. Two of his major works (the third being the later De la démonomanie des sorciers, which addresses a different set of questions), the Methodus of 1566 and the République of 1576, are conventionally seen as marking a remarkable shift in his thinking, with the République shedding the constitutionalist orientation of the Methodus and systematically developing a theory of royal absolutism. This shift is commonly associated with the St Bartholomew Day Massacre of 1572, which dramatically polarized French opinion and led Bodin, frightened by the rise of a revolutionary movement based on theories of legitimate resistance, to develop his unprecedented positions.

29 Julian H. Franklin, Jean Bodin and the Rise of Absolutist Theory (Cambridge: University Press, 1973), 102. Although there is now an ongoing debate about the extent to which Bodin actually had an absolutist conception of sovereignty at all, even in the République. For a brief overview of the literature, see Daniel Lee, Popular Sovereignty in Early Modern Constitutional Thought (Oxford: Oxford University Press, 2016), 161, note 12. Lee himself is quite radical in his approach and considers that Franklin erred in his interpretation, confusing popular sovereignty with popular resistance, and he seeks to 'dismantle the interpretive orthodoxy that Bodin was fundamentally hostile to popular sovereignty'. On the contrary, Lee claims, 'Bodin deserves to be properly recognized as perhaps the most important systematic early modern theorist of popular sovereignty' and a profound influence on Locke, Rousseau, and Sieyès (Ibid., 163.)

${ }^{30}$ Quaglioni, 'The Italian "Readers" of Bodin' 2013 (n. 22), 373.
} 
throne (1603), in The Trew Law of Free Monarchies. ${ }^{31}$ In order to support his position, Gentili cites Bodin even more frequently than Baldus (or Bartolus) as the most relevant authority on the matter of sovereignty, ${ }^{32}$ and combines Bodin's new theory with the Roman law principles of Princeps legibus solutus est ('the sovereign is not bound by the laws') and Quod Principi placuit, legis habet vigorem ('what pleases the prince has the strength of law'). ${ }^{33}$ Gentili makes his reliance on Roman law explicit: 'The civil law says that the princeps is unbound by the laws and that law is whatever pleases the princeps. This law is not foreign, but Roman: It is indeed the most excellent [praestantissima] among the laws of men'. ${ }^{34}$ Importantly, Gentili argued that these Roman law principles were directly applicable to the situation in England, ${ }^{35}$ and specifically, in an influential move within the English context, "that "absolute" authority was not an exclusively Roman notion, restricted only to those nations recognizing the civil law, but a universal one to be found in all independent states, including even in England' 36

\footnotetext{
${ }^{31}$ Koskenniemi, 'International Law and Raison D'état' 2010 (n. 5), 303. On Gentili's defence of absolutist principles, see also Alain Wijffels, 'Assolutismo Politico E Diritto Di Resistenza: La Disputatio Gentiliana "De vi civium in Regem semper iniusta"' (Alberico Gentili: L'usa della forza nel diritto internazionale. Atti Del Convegno Undicesima Giornata Gentiliana, San Ginesio, 18-19 Settembre 2004).

${ }^{32}$ Schröder, 'Vitoria, Gentili, Bodin: Sovereignty and the Law of Nations' 2010 (n. 22), 170.

${ }^{33}$ Koskenniemi, 'International Law and Raison D'état' 2010 (n. 5), 303.

${ }^{34}$ Gentili, Regales Disputationes, 9. Translation from Lee, Popular Sovereignty in Early Modern Constitutional Thought 2016 (n. 31), 278.

${ }^{35}$ Benjamin Straumann, 'The Corpus Iuris as a Source of Law Between Sovereigns in Alberico Gentili's Thought', in The Roman Foundations of the Law of Nations: Alberico Gentili and the Justice of Empire, ed. Benedict Kingsbury and Benjamin Straumann (Oxford: Oxford University Press, 2010), 101-25.

${ }^{36}$ Lee, Popular Sovereignty in Early Modern Constitutional Thought 2016 (n. 31), 278-9. As Daniel Lee explains in his chapter on 'Roman Law in Early Modern England', Gentili was 'among the first civilians to present a civilian account of how English royal authority was absolute - that is legibus solutus' and that his reasoning followed Bodin, thereby ensuring that 'civil law spoke with the voice of Bodin in England' (280, citing John Cowell, 'Prerogative of the King', The Interpreter, or, Booke Containing the Signification of Words (Cambridge, 1607), no page numbers). On the impact of civil lawyers in bringing absolutist political theory - primarily through the thought of Bodin - into England, see also Burgess's chapter on 'Civil Law, Sovereignty, and Absolutism, in Burgess, Absolute Monarchy and the Stuart Constitution 1996 (n. 29). Importantly, Burgess emphasizes that not all English civilians who are thought to have been Bodin-influenced absolutists were actually so (contesting the cases of Merbury, Forset, and Hayward), and that 'the clearest example of civil-law absolutism is to be found in the thought of... Alberico Gentili', an 'exotic figure' within this context considering his Italian Protestant background (75). It is in the work of Gentili, more so than in any of his English contemporaries, that we have 'a conception of "absolute" authority that, on the one hand, was linked to Bodinian theories of sovereignty, and, on the other, intimated a raising of the conception of absolute power into a transcendent authority over the law' (77).
} 
As I have noted earlier based on Figure 1 and Table 1, the influence of Bodin is also very deeply felt in DIB. While it is true that Bodin is not necessarily at the very top of the citation chart, he stands out for being extensively discussed in the text itself whenever he is mentioned. As Diego Quaglioni, drawing heavily on the earlier work of Alain Wijffels, ${ }^{37}$ explains: 'the references to the République form the framework of Gentili's De iure belli, from the first to the last page of the long treatise' and 'Gentili draws on Bodin's masterpiece not only for his absolutistic scheme of supreme power, but also for many arguments and formulae already proposed by the French jurist'. ${ }^{38}$ Bodin's doctrine, Quaglioni continues, 'seems to be the first and major source of Gentili's De iure belli, ${ }^{39}$ This may be somewhat of an overstatement; indeed, in addition to the fact that there are numerous authors cited many more times than Bodin in DIB, Peter Schröder reminds us that given the abundance of sources cited by Gentili, and his reliance - shared by his contemporaries, particularly the humanists - on a complex 'web of authors', it is somewhat risky to single out one author as the leading authority in the context of DIB, including Bodin himself on the discussion of sovereignty. ${ }^{40}$ That being said, and while Gentili does not always agree with Bodin when he cites him, the extent to which sections of DIB read as direct discussions of Bodin's arguments is indeed striking.

Quaglioni provides numerous examples of Gentili's discussion of Bodin in the text of $D e$ iure belli, along with a helpful analysis of what argument Gentili is making in each case, whether he is in agreement with Bodin or demarcating himself from him. I will not repeat this discussion here, but to give an idea of the breadth of topics on which Gentili cites Bodin-either

\footnotetext{
${ }^{37}$ Wijffels, 'From Perugia to Oxford' 2008 (n. 11).

${ }^{38}$ Quaglioni, 'The Italian "Readers" of Bodin' 2013 (n. 22), 376. See also Quaglioni, 'Pour une histoire du droit de guerre au début de l'âge moderne. Bodin, Gentili, Grotius' 2010 (n. 22), 38. 'Le Bodin de la République est le point de départ et la principale référence de la doctrine gentilienne'.

${ }^{39}$ Quaglioni, 'The Italian "Readers" of Bodin' 2013 (n. 22), 378.

${ }^{40}$ Schröder, 'Vitoria, Gentili, Bodin: Sovereignty and the Law of Nations' 2010 (n. 22), 170.
} 
approvingly or disapprovingly as a springboard for his own argument - these include the relationship with exiles, war in the defense of religion, the theory of self-preservation, preventive self-defense, defensive treaties, sureties given to enemies, hostages, expenses, damages from war, and slavery. ${ }^{41}$ In other words, throughout DIB, Gentili is extensively engaging with Bodin (République, overwhelmingly). He is not merely citing him in passing as a source of support or acknowledging him equally fleetingly as the exponent of a conflicting view, but actively dissecting Bodin's arguments and building up his own vis-à-vis those of the famous French jurist.

In addition, Bodin is cited at key moments in DIB — including within the first two pages of Gentili's treatise — which does support the idea that Gentili was drawing on Bodin in framing his arguments. And indeed, Alain Wijffels notes that the Gentili's manuscripts, held in the Bodleian's D'Orville collection, make clear that Gentili read République cover to cover while he was carrying out the preparatory work for DIB. ${ }^{42}$ Gentili's twenty pages of annotations on République closely follow the order of the six books, and the most often encountered annotation in the margins - the capital letter ' $\mathrm{B}$ '-is believed to stand for 'bellum' and thus to indicate the passages used in DIB. ${ }^{43}$ Thus, it is clear at the very least that Gentili had read the République very attentively, and that he profoundly admired Bodin's work, even if on certain points, such as the question of slavery, he occasionally did find Bodin 'exceedingly silly'. ${ }^{44}$ All in all, what comes across from Gentili's engagement with Bodin in DIB is, on the one hand, a constant back and forth between agreeing and disagreeing with Bodin on various specific issues, and, on the other hand, a broad acceptance of Bodin's wider principles, both in substance and in method.

\footnotetext{
${ }^{41}$ An in depth discussion of some of these examples can be found in Quaglioni, 'The Italian "Readers" of Bodin' 2013 (n. 22), 376-382.

${ }^{42}$ Wijffels, 'From Perugia to Oxford' 2008 (n. 11), 68-9.

${ }^{43}$ Ibid, 69.

${ }^{44}$ DIB, Book I, Chapter 9, §541.
} 
There are two core elements of Bodin's République that appear to have had a particularly important impact on the way Gentili framed his theory of the laws of war. First, Gentili draws heavily on Bodin in his method, praising his critique of modern commentators who seek to derive military law from Roman law alone. More specifically, Gentili 'appreciated Bodin's attempt to put in order and, so to speak, systematize the late-medieval tradition of ius gentium into a new comparative legal-historical doctrine' ${ }^{45}$ Like Bodin, Gentili was quite sympathetic to the criticisms of conventional approaches to Roman law waged by the French legal humanists, and he drew extensively from Bodin's methodology in developing his legal framework in DIB. While unlike Bodin, Gentili saw Roman law as timeless and thus directly applicable to all the problems of his day, ${ }^{46}$ he stepped away from the Bartolists' traditional uncritical and unconditional reliance on medieval authorities to analyze the Corpus iuris and drew instead on an extensive web of sources, notably giving pride of place to historians - both modern and classical—in his analysis. Bodin himself had broken off from the conventional mos gallicus and drawn extensively from both the legal humanists and the Bartolists in his attempt to elaborate a new legal system, an eclectic approach that must have appealed to Gentili. Gentili's discussion of Bodin on this point—which, as we shall see, also includes a critical dimension—appears at the very start of De iure belli, in the fourth paragraph of the first chapter, and clearly serves an important framing function for the work as a whole.

Second, Gentili quite clearly appears to be striving for a way to reconcile Bodin's absolutist conception of sovereignty with traditional understandings of the just war. As Quaglioni puts it, Gentili ‘did not ignore the ambiguity of Bodin's concept of just war, the

\footnotetext{
${ }^{45}$ Quaglioni, 'The Italian "Readers" of Bodin' 2013 (n. 22), 383.

${ }^{46}$ This is particularly striking when Gentili defends the application of Roman law to constitutional issues of his day, as discussed in Straumann, 'The Corpus Iuris as a Source of Law Between Sovereigns in Alberico Gentili's Thought' (n. 37), 106-8.
} 
difficulty of finding in it a clear definition, and especially the problem of adapting it to Bodin's concept of supreme power (summa potestas) ${ }^{47}$ It is true that Bodin had in fact written 'a complex elaboration on the concept of just war and more generally of an international law doctrine for $\mathrm{it}^{48}$ in République, Book VI, chapters 5 and 6 . However, it is not clear whether or not Gentili was actually aware of it, as he only cites the Latin text in DIB and therefore may never have read the French edition which Bodin expanded between 1576 and $1583 .{ }^{49}$ In any case, it is obvious from Book I, Chapter 3, entitled 'War is Waged by Sovereigns' that Gentili's considerations on war were driven by the question of how to reconcile supreme authority with ideas about the just war, and one detects in his work a palpable sense of urgency fostered by the intractable wars that were decimating Europe at the time.

Although he does not explicitly cite Bodin in the chapter, the fact that he is indebted to the Frenchman for his conceptualization of sovereignty is hard to miss, and it is unsurprising to note how heavily—and this time, explicitly_Gentili came to rely on Bodin's ideas in his seminal defense of absolutism, De potestate regis absoluta a few years later. Bodin defined sovereignty according to the four following principles: it had to be supreme (no superior except for God), absolute (the sovereign cannot be tried, unless he explicitly consents to it), indivisible (it is metaphorically held in only one set of hands, such as the King or Parliament — but not both), and perpetual (it cannot be changing hands). ${ }^{50}$ The sovereign had a specific set of prerogatives held by them alone, most importantly the right to make laws, the 'one attribute above all others', which 'included the privilege of declaring war and concluding peace, as well

\footnotetext{
47 Ibid. See also Quaglioni, 'Il "Machiavellismo" Di Jean Bodin (' République', V, 5-6)', Il Pensiero Politico 22:2 (1989), 198-207.

${ }^{48}$ Quaglioni, 'The Italian "Readers" of Bodin' 2010 (n. 22), 383.

${ }^{49}$ Quaglioni, 'The Italian "Readers" of Bodin' 2010 (n. 22), 383.

50 This definition of maiestas or summum imperium can be found in Jean Bodin, Les six livres de la République, Corpus des œuvres de philosophie en langue française (Paris: Fayard, 1986), Book I., viii. For a brief analysis, see Richard Bourke and Quentin Skinner, Popular Sovereignty in Historical Perspective (Cambridge: Cambridge University Press, 2016), 2.
} 
as the right of selecting the highest magistrates in the state. ${ }^{51}$ Echoing these ideas very closely, Gentili begins the chapter by stating that sovereigns are 'supreme', that they 'acknowledge no judge or superior', and that 'they alone merit the title of public, while all others are inferior and are rated as private individuals'. 52 'The sovereign', he continues, 'has no earthly judge, for one over whom another holds a superior position is not a sovereign' ${ }^{53}$ The central idea of the chapter, that only sovereigns can make war, also closely follows Bodin's ideas, particularly as private wars and mixed wars (public/private) were still a dominant feature of the age. Gentili repeats and expands on the latter theme in Book I, Chapter 10 ('On the Compacts of Leaders'), emphasizing that sovereigns 'alone can make agreements binding on the state', that the sovereign 'alone can make war, therefore he alone can end it', and 'just so it is said that only the sovereign can give a safe-conduct, since he alone can suspend sentence and give immunity from the consequences of a crime, ${ }^{54}$

There are, it is important to note, a few elements in the DIB that seem less aligned with Bodin's ideas. This raises two interrelated questions: first, how should these elements be understood within Gentili's broader framework? In other words, why might these passages be included in light of their apparent incompatibility with the rest of Gentili's approach? Second, may this suggest that five years before the publication of the incontestably absolutist and Bodinian Regales disputationes tres, Gentili was in fact, and despite relying on Bodin very extensively, not an absolutist yet? As I have mentioned, the debate over the extent of Gentili's absolutism has been tainted by political motives, with Gentili's opponents pointing to his absolutist leanings as a way to undermine his broader reputation, particularly during his revival

\footnotetext{
51 Ibid., 3.

${ }^{52}$ DIB, Book I, Chapter 3, §23.

53 Ibid.

${ }^{54}$ DIB, Book I, Chapter 10, $\$ 288$.
} 
in the late nineteenth century when the accounts of his 'greatness' as an international jurist were systematically elaborated. Since it is now well-established that Gentili made his absolutism eminently clear in the Regales disputations tres, I will address the main elements in DIB that may suggest he held a different position a few years earlier and argue that these should be understood primarily as exceptions made in light of the surrounding political context and of Gentili's personal obligations.

First, it is true that, as Van der Molen notes, on certain points, Gentili's absolutism is not as stark in DIB as it is in the Regales disputationes tres. ${ }^{55}$ Yet, the caveats to sovereign authority that Gentili introduces are hardly incompatible with an absolutist position. For example, Gentili puts forward certain limitations to absolute sovereign power within very specific cases, notably in his discussion of the rather extreme situations where a sovereign would alienate her subjects (i.e. make them subjects of another sovereign) or abandon them altogether. ${ }^{56}$ While this does suggest some limitation to sovereign power, Gentili makes it very clear that these limitations are minimal and mainly intended to avoid tyranny: 'Imagine that the emperor has the freest possible power; yet it is not for purposes of tyranny, but of administration. ${ }^{57}$ The distinction between an all-powerful king and a tyrant was actually quite common, including in Bodin's writing, and Bodin himself considered tyrannicide allowable (something which Van der Molen finds 'strange ${ }^{58}$ ). And in fact, while Van der Molen highlights the existence of restrictions to the rights of the sovereign found in DIB 'in spite of no fewer than thirty-five references to Bodin's

\footnotetext{
${ }^{55}$ Van der Molen, Alberico Gentili and the Development of International Law 1968 (n. 29), 227-230.

${ }^{56}$ DIB, Book I, Chapter 23, $\$ 185$.

${ }^{57}$ DIB, Book III, Chapter 15, §610.

${ }^{58}$ Van der Molen, Alberico Gentili and the Development of International Law (n. 29), 227.
} 
"De Republica," it is worth noting that Bodin himself introduced a number of such restrictions in his masterpiece. ${ }^{59}$

Second, at the end of his crucial chapter, 'War is Waged by Sovereigns', Gentili does raise some difficult questions and introduces some additional caveats in his conceptualization of sovereignty, this time with direct references to his geopolitical environment. Most notably, he makes some pragmatic concessions regarding the status of "states such as Venice," which he considers to "have the same power as any supreme sovereign'. ${ }^{60}$ However, this is not entirely surprising, as Bodin's definition of sovereignty raised some extremely difficult questions for the established order in most countries, including France which had long had a mixed constitution, and most importantly for the Holy Roman Empire. Following the publication of the République, there was an almost panic-stricken debate amongst German jurists about how to reconcile Bodin's ideas with the realities of the feudal empire, which would last for over thirty years. ${ }^{61}$ Gentili, who by definition had to engage with the existence of different forms of polities on the international stage in devising his system of laws, was left in a similarly uncomfortable position by Bodin's arguments, and to some extent he tried to make some space for a slightly looser definition of sovereignty in the context of the right to wage war.

Finally, the section most at odds with Gentili's broader absolutist leanings in DIB can be found in his chapter entitled 'Defending the Subjects of Another Against Their Sovereigns,'62 which would have been directly relevant to the question of whether it was legal for the English to support Dutch subjects in their rebellion against the Spanish. This seems to be the only passage

\footnotetext{
${ }^{59}$ Franklin, Jean Bodin and the Rise of Absolutist Theory (n. 31), Chapter 5.

${ }^{60}$ Ibid.

${ }^{61}$ Julian H. Franklin, 'Sovereignty and the Mixed Constitution: Bodin and His Critics (1991)', in The Cambridge History of Political Thought 1450-1700, by J. H. Burns and Mark Goldie (Cambridge: Cambridge University Press, 1991), 309-328.

${ }^{62}$ DIB, Book III, Chapter 16.
} 
in the text in which Gentili appears to be going in a completely different direction, contradicting himself on nearly everything else he has put forward in DIB regarding the nature of sovereignty, the right to war, and the legitimacy of rebellion. In addition to legitimizing the English intervention in favor of the Dutch, he makes a U-turn on his exclusion of 'those who have revolted' from the protection of laws of war ${ }^{63}$, as well as on his broader, crushing indictment of rebels ${ }^{64}$ and suggests that the Dutch may in fact be entitled to rebel against the Spanish, because they have acquired enough power to 'share as it were in the sovereignty'. 'They are', he continues, 'public characters and on an equality with the sovereign, just as one sovereign is said to be on an equality with another when he is able to resist the other in an offer of violence. ${ }^{65}$

If anything, what this chapter does is illustrate the extent to which Gentili's new framework for the laws of war put him in an awkward position vis-à-vis his own allegiances. Due to his circumstances, as a Protestant exile in England with close ties to the Court, it was unthinkable for Gentili not to support the Dutch Revolt in DIB, even if this meant contradicting himself quite extensively. Ultimately, this chapter is fascinating because its content was so directly relevant to the main conflict of Gentili's time, and it neatly illustrates the tension between the framework Gentili was trying to develop and the political realities he had to personally navigate. It is hard to see how Gentili could have argued anything else on this particular topic. Obviously, claiming that in rebelling against the Spanish the Dutch were violators of the law of nations was simply not an option. Gentili therefore had to perform an incongruous intellectual pirouette and quietly contradict himself for the sake of political bienséance.

\footnotetext{
${ }^{63}$ DIB, Book I, Chapter 4, $\S 36$. Gentili reiterates his claim that rebels are akin to pirates and thus cannot be considered proper 'enemies' in DIB, Book I, Chapter 4, $\S 41$.

${ }^{64}$ DIB, Book III, Chapter 8, especially $\$ 521-522$.

${ }^{65}$ DIB, Book I, Chapter 16, §120.
} 
Gentili can thus evidently be understood as already having been an absolutist in DIB, with his reliance on Bodin further deepening in the following years. However, in light of Gentili's difficulty in adapting some of Bodin's ideas to the geopolitical configurations of his time, it is clear that there were some limits to how far Gentili could rely on the République to develop his arguments for DIB, particularly in the sense that DIB was specifically geared towards regulating relations between sovereign states. Bodin's 'great concern, like that of the whole group of "politique" jurists, was civil war and the good and unity of France'. ${ }^{66}$ As a result, these thinkers 'had little to say about any law applicable in France's external relations beyond what was said by Bodin about there being absolutely no real universal empire and that only a kind of ius fetiale regulated the relations between sovereigns' ${ }^{67}$ Yet, these external relations were precisely what Gentili was concerned with. In fact, Bodin's chapter in the République on the ancient ius fetiale (and on treaties and peace) ${ }^{68}$ is 'one of the most extensively annotated chapters in Gentili's manuscript notes, and, correspondingly, one of the most frequently quoted chapter from Bodin's book in Gentili's De iure belli' ${ }^{69}$ In other words, Bodin's ideas were of great appeal to Gentili, who attempted to draw on as much of Bodin's work as he could in light of his own interests, but there were clearly some areas that were central to Gentili's endeavor which Bodin had not covered sufficiently.

Most importantly, Bodin's ideas on sovereignty had significant implications for interstate relations, and raised one particularly delicate issue. His all-important concept of the Commonwealth [République], the entity to which his concept of indivisible and absolute sovereignty was to apply, was the central element of his plan for restoring order. Within each

\footnotetext{
${ }^{66}$ Koskenniemi, 'International Law and Raison D’état' 2010 (n. 5), 308.

${ }^{67}$ Ibid.

${ }^{68}$ Bodin, République, Book V., vi (n. 43).

${ }^{69}$ Wijffels, 'From Perugia to Oxford' 2008 (n. 11), 70.
} 
Commonwealth, a single sovereign authority would have the power to arbitrate disputes and establish final rules, thus providing a way out of otherwise intractable confessional strife. At a time where constitutional arrangements had been the norm in France, with the King expected to respect the rules of consent and work with institutions such as the General Estates and the Parlement of Paris, Bodin's defense of indivisible and absolute sovereignty was a bold conceptual move, bolder than even he ever seemed to realize. ${ }^{70}$ Bodin's concept of the Commonwealth stood as a powerful tool for re-establishing order and stability within France and other similar kingdoms. However, it raised a problem at a higher level. If each Commonwealth was characterized by indivisible sovereignty, and if each prince was thus the highest authority deciding upon all matters of the land, then how would one settle disagreements amongst Commonwealths? This was a critical question at a time when, following the Reformation and the collapse of the religiously united Latin West, the emerging sovereign state had all of the sudden achieved external sovereignty, ${ }^{71}$ and as with the question of how to define sovereignty within the Holy Roman Empire, Bodin appears to have launched a seminal debate which he himself was not necessarily interested in. The issue of settling disagreements amongst Commonwealths is the main problématique underpinning DIB, and Gentili found little by means of an answer in Bodin's work.

Importantly, this question arose within a broader move towards the emancipation of the laws of war from the law at large and the gradual emergence of the ius belli as a new discipline. ${ }^{72}$ By the second half of the sixteenth century, 'the genre of self-standing treatises [on the laws of war] imposed its own rules', which meant that authors could 'isolate the relevant texts from the

\footnotetext{
${ }^{70}$ Franklin, Jean Bodin and the Rise of Absolutist Theory 1973 (n. 31, 102).

${ }^{71}$ Lesaffer, 'Alberico Gentili's Ius Post Bellum and Early Modern Peace Treaties' 2010 (n. 11), 216. More broadly, see Lesaffer, 'The Classical Law of Nations (1500-1800)' 2011 (n. 20), 408-422.

${ }_{72}$ Haggenmacher, 'Il diritto della guerra et della pace di Alberico Gentili', Atti del convegno Quarta Giornata Gentiliana 21 Settembre 1991 (Milan 1995), 36-37.
} 
glossators, commentators, and humanist jurists on the laws of war and military discipline from the rest', leaving out 'direct references to rules of private law from the Justinian and canon collections and the glosses thereon'. ${ }^{73}$ This is clear in the works of the two most famous sixteenth century jurists of war (prior to DIB) - Pierino Belli (1505-1575) and Balthazar Ayala (1548-1584), both Roman law specialists and military judges — who took important steps in that direction. Gentili, however, took 'a second important step ${ }^{, 74}$ in also emancipating his treatise on the laws of war from non-legal considerations of the rules of military discipline. As such, DIB constituted the first treatise solely concerned with 'the laws regulating warfare between independent bodies politic', marking a significant turning point in 'the emergence of the ius belli as the hardcore of a future "ius inter gentes", ${ }^{75}$ a law between independent, sovereign peoples.

In sum, while Bodin and the politiques were concerned with how best to ensure order in France, Gentili was actively trying to cope with the consequences of Bodin's conceptual move for the international plane, and to develop a standalone set of rules for managing the conflicts that would inevitably arise between independent and absolutely sovereign polities. ${ }^{76}$ Thus, while it is true that 'what is evident from the outset of [DIB] is that [Gentili] departs-despite his admiration for Baldus and the Corpus iuris civilis - towards an innovative discussion of interstate relations, which is clearly informed by the use of Bodin's République,${ }^{77}$ Bodin cannot have been Gentili's sole (or even main) source of inspiration for his considerations on inter-state

\footnotetext{
73 Ibid.

${ }^{74}$ Lesaffer, ‘Alberico Gentili’s Ius Post Bellum and Early Modern Peace Treaties’ 2010 (n. 11), 216.

${ }^{75}$ Ibid.

${ }^{76}$ In fact, one of the main interpretations of the puzzling De armis Romanis it that is is an attempt to justify the application of the Corpus iuris to inter-sovereign relations. Straumann, 'The Corpus Iuris as a Source of Law Between Sovereigns in Alberico Gentili's Thought' 2010 (n. 37), 120-1. This interpretation is supported by Anthony Pagden, see Pagden, 'Gentili, Vitoria, and the Fabrication of a "Natural Law of Nations"' 2010 (n. 20), 340-341.

${ }^{77}$ Schröder, 'Vitoria, Gentili, Bodin: Sovereignty and the Law of Nations' 2010 (n. 22), 171.
} 
relations. For this, he turned to reason of state writers who, by contrast with Bodin, had written extensively about the international.

\section{Thinking the international: the influence of the ragion di stato tradition}

The most famous treatise on raison d'état, Botero's Della Ragion di Stato was published just three years (1586) before Gentili's lectures on the laws of war, and Gentili was clearly influenced by this intellectual courant, particularly in DIB. Indeed, one of the most striking influences on Gentili in DIB is Guicciardini, whom he cites no less than sixty-three times, nearly twice as many times as Bodin (although the latter tends to be discussed more directly in the text). This extensive reliance on the Florentine author denotes Gentili's admiration, indirectly, for Machiavellian policies. The fact that Gentili relies much less on Machiavelli-whom he does cite but only on three occasions, and referring neither to the Prince nor to the Discorsi-may well be a result of the stigma that was associated with Guicciardini's friend, and would be very much in line with the attitude adopted by later reason of state writers. As Burke explains, one of the primary problems for these writers was that while they strongly disliked Machiavelli- he was seen as the master of the devil's reason of state - they could not do without his ideas. ${ }^{78}$ Guicciardini, who put forth a set of considerations similar to those of his Florentine friend, was a much more palatable authority to cite. Similarly, in DIB Gentili makes over fifty citations of the Roman historian Tacitus, whose revival was deeply intertwined with the development of the ragion di stato literature, and who is sometimes said to have been a direct cover for references to

\footnotetext{
${ }^{78}$ Peter Burke, 'Tacitism, Scepticism, and Reason of State', in The Cambridge History of Political Thought, 14501700, ed. J. H. Burns and Mark Goldie (Cambridge: Cambridge University Press, 1991), 483.
} 
Machiavelli. ${ }^{79}$ Another possible explanation is that while Machiavelli was nearly obsessed with the Romans, Guicciardini drew much more on the contemporary world, particularly Florentine history, something which must have appealed greatly to Gentili, whom as we have seen relied on contemporary historians to an uncommon degree. In any case, beyond these mere numbers in terms of citation, it is quite obvious that Gentili thought about the ragion di stato writers-and particularly of Guicciardini-very highly. In fact, Gentili explicitly writes that Guicciardini is 'not merely a great historian and a political philosopher, but a great jurist as well' ${ }^{80}$

It is true that Gentili only cites Guicciardini's Storia d'Italia (History of Italy); there is no mention of his Ricordi politici e civili, his collection of maxims on political, social, and religious topics. However, it is clear that Gentili heavily draws on Guicciardini's work for its matter-offact understanding of politics so central to the reason of state tradition, more so than as a source of purely illustrative historical anecdotes. For instance, he cites him to support the claim that sovereigns often cloak their dishonesty in religion, ${ }^{81}$ to explain the rejection of Luther's doctrines (they are 'unfavourable to the power of princes'), ${ }^{82}$ to praise the policies of Lorenzo de Medici, 'that wise man, friend of peace, and father of peace' who ensured 'that the balance of power should be maintained amongst the princes of Italy ${ }^{83}$ to suggest that princes will only come to the rescue of oppressed people if they are 'led by a desire for personal gain, ${ }^{84}$ to point outrather irreverently - that it is 'characteristic of pontiffs not to keep their promises' and that it is 'an established custom for the Church, regardless of contracts, promises, or receipt of favours, to renounce its obligations and even directly to oppose what the prelates had solemnly agreed

\footnotetext{
${ }^{79}$ Giuseppe Toffanin, Machiavelli e il 'tacitismo': la 'politica storica' al tempo della controriforma (Padova: ADraghi, 1921), 12.

${ }^{80}$ DIB, Book II, Chapter $8, \S 167$. Gentili reiterates this, calling him 'the famous historian and eminent jurist', DIB, Book III, Chapter II, §483.

${ }^{81}$ DIB, Book I, Chapter 9, $\$ 63$.

${ }^{82}$ DIB, Book I, Chapter 10, $\$ 43$.

${ }^{83}$ DIB, Book I, Chapter 14, §105.

${ }^{84}$ DIB, Book I, Chapter 15, §115.
} 
upon', ${ }^{85}$ and the list goes on. On at least one occasion, a remark Gentili makes based on Guicciardini's historical writings virtually sounds like one of the latter's maxims: 'it is a grave error to consider what ought to be done, not what a man will do who has the power to act' ${ }^{86}$ In fact, when he elaborates this point and explains that 'every pledge is capable of being broken', he cites Tacitus approvingly, claiming that 'the statement of Tacitus is always true, that enduring faith never exists between victors and vanquished'. ${ }^{87}$ What is more, Gentili seems to disagree explicitly with Guicciardini on just one occasion, on the question of whether Kings should 'fight in single combat for the dominion to which both sides laid claim, ${ }^{88}$ a rather minor details in light of the extent to which Gentili draws on Guicciardini otherwise.

What, then, were the main insights of this reason of state tradition so extensively drawn on by Gentili? The remainder of this section lays out the core features of the reason of state literature, outlining the context in which it emerged, the basic tenets of the new strand of thought it ushered in, and the sources it turned to-particularly Tacitus, another key influence on Gentili's DIB. Most importantly, the reason of state writers developed a set of principles that could be applied not just domestically, but also-and explicitly-to relations between sovereigns. As I have briefly indicated earlier, there is no doubt that, for his part, Gentili was deeply concerned by the regulation of inter-sovereign relations and the specific problem of how to resolve conflicts between sovereigns, whom he saw as recognizing no superiors by definition. ${ }^{89}$ During his eventual revival, he would in fact come to be celebrated notably for his remarkable advocacy of international arbitration, which he portrayed as an alternative to war,

\footnotetext{
${ }^{85}$ DIB, Book III, Chapter 19, §403.

${ }^{86}$ DIB, Book III, Chapter 13, §584.

${ }^{87}$ DIB, Book III, Chapter 13, §584.

${ }^{88}$ DIB, Book III, Chapter 15, $\$ 607$.

${ }^{89}$ DIB, Book I, Chapter 2, §18.
} 
'the arbitrament of Mars. ${ }^{90}$ It is thus not entirely surprising that in light of the limitations of Bodin's rather inward-looking text, Gentili turned to those writers who seemed most explicitly interested in addressing the issues raised by inter-sovereign relations.

At its core, the rise of reason of state thinking marked a transition from the Renaissance concept of politics as 'the art of ruling a republic according to justice and reason' (paraphrasing Latini's famous definition of 1266) to a new understanding of politics as the means of preserving a state, or in other words, politics as the knowledge of the means of preserving domination over a people (paraphrasing Botero's equally famous formulation of 1586). ${ }^{91}$ The Renaissance concept of politics, sometimes also couched as the art of good government, had flourished in the age of Civic Humanism; its principles were rooted in traditions of political virtue, civil law and Aristotelianism, ${ }^{92}$ and the model it sought to follow was that of the Roman republic, as described by Cicero and Livy. Machiavelli and Guicciardini, although they were both symptomatic of a transitional epoch and in many ways remained anchored in the tradition of politics as the art of the republic, took some important steps in a different direction, which Guicciardini would, in the 1520 s first term 'reason of state'. Their key contribution was to carve out a new space of morality, one that applied distinctly to the prince's task of 'maintaining the state' (mantenere lo stato) and which could entail using certain means that would otherwise have been condemned as immoral.

Two elements are particularly important here. First, they argued that the prince should readily use force when in the interest of the state; second, they placed prudence - rather than justice - as the heart of their system of princely virtues. In other words, although much of their

\footnotetext{
${ }^{90}$ DIB, Book I, Chapter 3, $\$ 32$.

91 Maurizio Viroli, From Politics to Reason of State: The Acquisition and Transformation of the Language of Politics, 1250-1600, Ideas in Context ; 22 (Cambridge: Cambridge University Press, 1992), 2-3.

92 Ibid., 2.
} 
approach was still grounded in the Florentine republican tradition, they put forward a revolutionary analysis of what should count as virtuous behavior for a prince, discarding the traditional approach based on personal virtue. They made, in modern terms, 'a virtue of necessity', and they broke down the classical divide between violence and virtue, arguing — most famously in the case of Machiavelli - that because of the circumstances of reality, it was sometimes necessary to act in beastly ways, like the fox and the lion (turning Cicero's classic quote on its head, that ' $[\mathrm{w}] \mathrm{hile}$ wrong may be done, then, in either of two ways, that is, by force or by fraud, both are bestial: fraud seems to belong to the cunning fox, force to the lion; both are wholly unworthy of man... ${ }^{93}$ ). Ultimately, these writers were advocates of pragmatic compromises and the use of sometimes ruthless methods to ensure the well-being of the state; as explained by Guicciardini, one simply could not govern a state according to conscience'.94

In developing these ideas, Machiavelli, Guicciardini, and their contemporaries were responding to the challenges of their time. After years of flourishing republican government, Florence was torn between its republican antecedents and the rule of the Medici, changing governments four times between 1494 and 1530. In light of the atmosphere of considerable political instability — and not unlike the French politiques a few decades later - these writers became increasingly concerned with how to avoid, above all, the collapse of the state. In his quest for answers, Guicciardini, in particular, turned not to Livy and Cicero, who had written during the heydays of the Roman republic, but to Tacitus, whose Annals, in particular, pertained to the unstable transitionary period between the republic and the empire in the aftermath of Caesar's assassination in 44 BCE. Guicciardini's turn to this other classical historian was central to his ideology and eventually became widely popularized by Justus Lipsius, whose inauguration

\footnotetext{
${ }^{93}$ Cicero, De Officiis, I, 41.

94 Francesco Guicciardini, Dialogue on the Government of Florence, trans. Alison Brown (Cambridge University Press, 1994), 159.
} 
lecture at the university of Jena is 'one of the most dynamic applications of Tacitus to politics in the Renaissance'. ${ }^{95}$ Although this particular lecture was not published until 1607, Lipsius (who is cited thirteen times in DIB) generally became the greatest Tacitus scholar and advocate of the crucial contemporary relevance of his work — seeing Livy's writings as 'sweet nothingness' in comparison ${ }^{96}$-and inspired an entire generation of thinkers to investigate Tacitus' writings. Lipsius' new edition of Tacitus's works in 1574 became the first of a very long series of reeditions, a testimony to an explosion of interest in the thought of the Roman historian. The key turning point, however, was again with Bodin, who criticized Machiavelli, More, Patrizi, and others for now having drawn sufficiently on Tacitus, and who, in his case for monarchy as the most excellent form of government, argued that Tacitus was 'the most useful ancient historian for illustrating the principles upon which monarchies operate ${ }^{97}$ His reevaluation of Tacitus as the go-to historian for political instruction on how to run a monarchical government was 'enlarged and refined by others' and this process was key to the eventual development of the reason of state tradition of the late sixteenth and seventeenth centuries. ${ }^{98}$ Thus, although much can be written about the differences between these individuals and their respective works, the names of Tacitus, Machiavelli, and Guicciardini became intertwined and perceived as the ideological basis of the 'reason of state' movement.

The practices put forth by Machiavelli were hugely controversial, and he and Tacitusnow couched as a classical precursor to the Florentine writer - came to be seen as advocates of a 'bad' reason of state, irreconcilable with Christian principles by the late sixteenth century. This was made especially clear from the late sixteenth century in the work of Botero and his

\footnotetext{
${ }^{95}$ Kenneth C. Schellhase, Tacitus in Renaissance Political Thought (Chicago ; London: University of Chicago Press, 1976), 118.

${ }^{96}$ Ibid.

${ }^{97}$ Ibid., 111.

${ }^{98}$ Ibid.
} 
contemporaries, and the distinction between 'good' and 'bad' reason of state became a classical trope of early seventeenth century thinking. ${ }^{99}$ The challenge, ultimately, for writers such as Botero, was to reconcile the insights of Machiavelli-which were extremely perceptive and uncontestably valuable - with a more palatable normative framework. As Comparato explains, 'behind the façade of deference and virtue which [late sixteenth century] writers presented, contemporary politics continued to reflect Guicciardini's maxim that "one cannot keep a state according to conscience", ${ }^{100}$ Crucially, in their attempt to respond to the unstable political atmosphere of their time, political thinkers continued to draw extensively on the analyses of historians such as Tacitus; not only did history provide princes with the 'experience' so central to the exercise of prudence, ${ }^{101}$ but the work of historians, stripped of illusions, appeared far more useful than the preaching of moralists. ${ }^{102}$ One of their key concerns in searching these historical texts for advice was how to navigate what had become an explosive network of external relations between sovereigns. Lipsius had famously compared the Duke of Alba to Tiberius, the Roman emperor described as a notorious tyrant by Tacitus, and indeed, the conflict between Spain, England, and the Low Countries was squarely on the mind of both legal and political thinkers at the time.

Raison d'état writers thus had a keen interest in the question of how best to conduct external relations, a fact that did not escape Gentili in his own attempt to grapple with the issue of inter-sovereign relations. This shared interest was not surprising in light of the developments

\footnotetext{
${ }^{99}$ This distinction between good and bad reason of state gradually lost traction in the seventeenth century, most notably through the seminal work of Henri Duc de Rohan, De l'intêret des princes et des États de la Chrétienté (1638). See Christian Lazzeri's 1995 introduction to Henri de Rohan, De l'intérêt des princes et des États de la chrétienté, ed. Christian Lazzeri (Paris: Presses Universitaires de France, 1995).

${ }^{100}$ Vittor Ivo Comparato and Diego Quaglioni, 'From Machiavellism to the End of the Seventeenth Century', in European Political Thought, 1450-1700: Religion, Law and Philosophy, ed. Howell A. Lloyd, Glenn Burgess, and Simon Hodson (New Haven, Conn; London: Yale University Press, 2007), 78.

${ }^{101}$ Ibid., 82.

${ }^{102}$ Ibid., 79.
} 
of the period: as the theoretical foundations of absolutism and reason of state in internal affairs became 'sufficiently comprehensive to provide ready-made justifications for the many measures... believed to be required by political necessity', ${ }^{103}$ foreign policy became an even more pressing topic. This is not to say that full internal sovereignty was achieved before or faster than external sovereignty. If anything, the process went the other way around, with sovereigns suddenly achieving external sovereignty after the collapse of the unity of the Latin West, while internally, struggles for power continued well into the eighteenth and even the nineteenth century. ${ }^{104}$ The point here is that in terms of legal rules, the basis for how the state would operate internally under an absolute sovereign was fairly clear, while by contrast, foreign policy 'was subject to no generally recognized principles, legal or moral', ${ }^{105}$ and thus required the development of some clear guidance for sovereigns.

In the broadest sense, raison d'état writers 'held it self-evident that the same principles and techniques that would ensure the strength of the prince's rule inside his realm would also be applicable in his external relations'. ${ }^{106}$ Prudence, necessity, and the interests of the state were systematically at the heart of their recommendations. This meant that, for instance, they considered the use of frauds and ruses to be perfectly acceptable in the conduct of external relations, although they did try to establish some rules of decency in the use of such stratagems in an effort to demarcate themselves from the notoriously more permissive Machiavelli. It was possible, Justus Lipsius argued, for virtue to remain intact if prudence was mixed with trickery with a good end. Lipsius then developed this 'Procrustean doctrine' in greater detail; he distinguished between light, medium, and great ruses and fraud, of which he only allowed the

\footnotetext{
103 William F. Church, 'The Decline of the French Jurists as Political Theorists, 1660-1789', French Historical Studies 5, no. 1 (1967): 37-38.

${ }^{104}$ Lesaffer, 'The Classical Law of Nations (1500-1800)' 2011 (n. 20), 419.

105 Church, 'The Decline of the French Jurists as Political Theorists, 1660-1789' 1967 (n. 103), 37-38.

${ }^{106}$ Koskenniemi, 'International Law and Raison D’état' 2010 (n. 5), 308.
} 
first two. Light ruses and frauds, generally to be blamed on the victim rather than the author, 'did not depart seriously from virtue and included deceit and dissimulation'; medium ruses and frauds, which included 'the corruption of another ruler's emissaries and agents, the sending of spies abroad, and the spreading of information' were 'mid-way between virtue and open vice'; and finally, great ruses and frauds, such as 'the willful breaking of treaties and other sworn agreements, and injustice contrary to the highest legal and moral principles', were considered to break 'entirely with virtue and law, resulting in perfidy and injustice'. ${ }^{107}$

Gentili could find plenty to draw on from reading these writers who, unlike Bodin, directly addressed the realm of the international. However, while the limits they posited involved a certain respect for legal agreements, notably treaties, as a whole, reason of state writers had little consideration for the role of the law of nations in regulating relations between states. Their language was not that of law, but that of political necessity, state interest, and, especially from the 1590 s, balance of power. ${ }^{108}$ In fact, the growing influence of their ideas in the seventeenth century - the development of what may be called 'baroque statecraft' — went hand in hand with the demise of lawyers as influential figures in the conduct of politics, and particularly the conduct of external relations. ${ }^{109}$ For a jurist like Gentili, this was bound to raise some issues. While he did deeply admire the reason of state tradition, one decisive factor made him stand out sharply from this group: unlike them, he saw law as a crucial ingredient for external relations. ${ }^{110}$ In the final section, I will thus argue that DIB must be understood as a text that tries to adapt not

\footnotetext{
${ }^{107}$ William F. Church, Richelieu and Reason of State (Princeton: Princeton University Press, 1972), 60-62.

${ }^{108}$ Richard Tuck, Philosophy and Government, 1572-1651 (Cambridge: Cambridge University Press, 1993), 96.

109 The French case is particularly illustrative here. While the writings of someone like Bodin could be of tremendous importance for matters of government in the late sixteenth century, jurists increasingly stepped away from matters of public law in the seventeenth century. On the decline of the importance of jurists with the rise of raison d'état thinking through Richelieu and Louis XIV in the French case, see Church, Richelieu and Reason of State 1972 (n. 107); Church, 'The Decline of the French Jurists as Political Theorists, 1660-1789' (n. 103). On the specific chasm between raison d'état and international law, see Church, Richelieu and Reason of State 1972 (n. 107), 39.

${ }^{110}$ Koskenniemi, 'International Law and Raison D'état' 2010 (n. 5), 308.
} 
only Bodinian absolutism but also — and crucially — the insights of the reason of state writers to a system of laws for regulating interactions between independent sovereigns.

\section{Between law and politics}

In attempting to bridge the jus gentium and the reason of state tradition, Gentili was part of a long trend of trying to link political and legal thought together. In practice, lawyers had often been prominent figures in government, particularly in the critical context of Renaissance Italy. ${ }^{111}$ In other words, they were deeply involved in statecraft, and their professional work as lawyers often overlapped quite extensively with their careers as government officials. More broadly, prior to the development of the ragion di stato literature, the rule of law culture had been essential in 'the political governance of the late-medieval Italian polities where the law scholars and consultants of the mos italicus had thrived'. ${ }^{112}$ The result of this close overlap between law and politics was a significant effort on the part of lawyers to engage with questions of politics, and they did so specifically by turning to history. Although this turn to history would become most apparent — and most systematic — in the works of Baudouin and Bodin ${ }^{113}$ in the second half of the sixteenth century, this inter-disciplinary engagement had a long pedigree, with Bartolus being one of the first legal thinkers to write not simply as a lawyer but also as a historian.

As mentioned earlier, Bodin's work marked a turning point in that Bodin tried to base his construction of a new system of law on universal history. Bodin's turn to history was very much in line with what Machiavelli had attempted earlier in the century (and indeed, Bodin praises

\footnotetext{
${ }^{111}$ Lauro Martines, Lawyers and Statecraft in Renaissance Florence (Princeton: Princeton University Press, 1968).

112 Wijffels, 'From Perugia to Oxford' 2008 (n. 11), 78. See also Ibid., 63.

113 See, generally, Franklin, Jean Bodin and the Sixteenth-Century Revolution in the Methodology of Law and History 1966 (n. 12). On the specific role of François Baudouin in attempting to reconcile law and history, see also Donald R. Kelley, Foundations of Modern Historical Scholarship: Language, Law, and History in the French Renaissance (New York; London: Columbia University Press, 1970), 116-148.
} 
Machiavelli's method on this front in the Methodus), and this overlap is very much connected to these thinkers' focus on the prince as the sovereign. Since the focus, both for Machiavelli in The Prince and for Bodin in his advocacy of absolutism, was on the person of the supreme sovereign, they found it essential to unearth the history of former princes and assess the actions they had taken. As suggested earlier, history was, after all, a treasure trove of 'experience' that would help princes (and their advisers) determine how best to act prudently. ${ }^{114}$ Yet, while Bodin and Machiavelli have often been juxtaposed as founders of a modern discipline of political science, ${ }^{115}$ Bodin's emphasis on legal thought meant that in terms of method the two writers were 'literally worlds apart'. ${ }^{116}$ Bodin, by virtue of his training and intellectual affinities'worked in a much richer-and more inhibiting — context of legal, historical, and philosophical erudition' than Machiavelli, and he was 'unable to separate politics from its legal and social environment'. ${ }^{117}$ In this respect, Kelley points to the insightful remark of one of 'Bodin's most perceptive commentators', Moireau-Reibel: 'the Republic is the work not so much of a great politique as of a great legist, the work of a successor not of Machiavelli but of Beaumanoir and Bartolus'. ${ }^{118}$ In other words, what jurists such as Bodin and his followers were doing was distinct from the reason of state writers in that they considered law to be at the center of their intellectual endeavor and placed it in direct dialogue with politics and history.

Gentili, deeply influenced as he was by Bodin, was very much a follower of this approach, and notwithstanding his admiration for the reason of state writers, he made a sustained effort to 'assert the authority of the law of nations' which he was contributing to 'formulate as a

\footnotetext{
${ }^{114}$ Comparato and Quaglioni, 'From Machiavellism to the End of the Seventeenth Century' 2007 (n. 108), 82.

${ }^{115}$ It is worth mentioning that Bodin had rather mixed opinions about Machiavelli. While he praised him for his methodological innovations, particularly in the Methodus, he depicted his ideas about the prince as devilish in République.

${ }^{116}$ Kelley, Foundations of Modern Historical Scholarship 1970 (n. 113), 146.

${ }^{117}$ Ibid., 145 .

${ }^{118}$ Ibid.
} 
distinct and autonomous legal discipline'. ${ }^{119}$ This attempt to reconcile the two approaches, particularly once combined with the initial tensions raised by the application of Bodinian absolutism to a jus gentium framework, put Gentili in a slightly difficult position here. On the one hand, he was a key advocate of absolutism, and in justifying his position, he had made much of the medieval distinction between the ordinary and extraordinary powers of the prince in a domestic context, thus limiting the constraints imposed on the prince by public law to the realm of ordinary power. ${ }^{120}$ In other words, in the domestic context Gentili had tried to free the sovereign from the constraints of the law by expanding the scope of the prince's extraordinary powers and thus the primacy of the prince's discretion over the rule of law. In practice, sovereigns were indeed gradually shifting towards more absolutist forms of rule, and what had been 'extraordinary' powers in the Middle Ages were now increasingly become part of the 'ordinary' category. On the other hand, the autonomy of the law of nations which Gentili was seeking to establish in $\mathrm{DIB}^{121}$ risked being strongly undermined by the rise of supreme sovereigns acting as the sole legitimate actors internationally and actively pursuing the interest of their polity according to the principles of reason of state. It was thus key for Gentili to find a way to maintain the early-modern sovereign within the late-medieval Italian culture of accepting the constraints of the law. Gentili thus turned to a variety of sources-from those of his Perugian heritage to the work of Bodin - in order to try and adjust to early modern sovereignty the law of nations as conceived in the mos italicus that had been so central to the government of latemedieval Italian polities. ${ }^{122}$

\footnotetext{
${ }^{119}$ Wijffels, 'From Perugia to Oxford' 2008 (n. 11), 78.

${ }^{120}$ Ibid., 64.

${ }^{121}$ Ibid., 77.

${ }^{122}$ Ibid., $77-78$.
} 
As I have suggested earlier, by the time he wrote DIB, Gentili was not exactly a staunch follower of the mos italicus anymore and he may well have been following Bodin in cherry picking what he found most useful in both the Bartolist and the legal humanist traditions in his construction of a new legal framework. ${ }^{123}$ Bodin's work, in addition to the justification it provided of absolutism as discussed in part II, was indeed crucially important to Gentili on two further counts here. First, his systematic approach had been hailed-in Protestant countries but also in Catholic ones despite the condemnation of his books by Roman Catholics - 'as a new model of scholarly teaching of public law'. ${ }^{124}$ Indeed, Bodin's 'hyper-rationalizing tendencies ${ }^{125}$ had led him to approach the law in a way that would prove enormously influential for later jurists interested in systematizing the law of nations. Second, his extensive considerations on sovereignty, his rigorous attempt to clarify what this concept meant in precise legal terms, and more broadly, his attempt to fuse the language about power and interests with the language of rights and authority ${ }^{126}$ provided an essential resource for Gentili in trying to adapt the insights of ragion di stato to his legal framework.

The specific challenge Gentili faced, however, was to reconcile the law of nations both with reason of state thinking and with his ringing endorsement of absolutism. It is with respect to the latter than Gentili and the theologians can be seen as explicitly political rivals, as the theologians' natural law theories grew out of their anti-Machiavellian stance and became the

\footnotetext{
${ }^{123}$ On Bodin's turn to practice, his admiration for the Bartolism on which the practice of law relied, his move away from (or rather beyond) legal humanism, and his attempt to combine the best of both the mos gallicus and the mos italicus and overcome their respective (as well as overlapping) limitations, see Donald R. Kelley, 'The Development and Context of Bodin's Method', Jean Bodin: Verhandlungen Der Internationalen Bodin-Tagung (Munich: $\mathrm{CH}$ Beck, 1973), 123-50.

${ }_{124}$ Quaglioni, 'The Italian "Readers" of Bodin' 2013 (n. 22), 372.

${ }^{125}$ Kelley, 'The Development and Context of Bodin's Method' 1973 (n. 123), 144.

${ }^{126}$ Franklin, Jean Bodin and the Rise of Absolutist Theory 1973 (n. 31).
} 
basis for their broader anti-absolutism. ${ }^{127}$ Indeed, they rejected 'not only autocratic forms of government but absolute monarchy altogether', leading to a lengthy controversy over what exactly natural and divine law 'meant, enjoined, allowed, and restricted' ${ }^{128}$ Gentili's challenge on this point, then, was to find a way to reconcile natural law theories with his absolutist position, a rather difficult (if not seemingly contradictory) endeavor. ${ }^{129}$ Ultimately, Gentili's DIB is thus peculiar in that it tries to bring together the implications of Bodin's writings - both on absolutism and on the use of universal history as a way to ground a new system of law-and the remarkably insightful but also (particularly for a jurist) deeply challenging ideas of the raison d'état writers about relationships amongst independent polities into a framework for the laws of war still anchored in the language of natural law.

127 Gerhard Oestreich, Neostoicism and the Early Modern State, Cambridge Studies in Early Modern History (Cambridge: Cambridge University Press, 1982), 259.

${ }^{128}$ Ibid.

${ }^{129}$ As Alain Wijffels emphasizes, it seems a priori difficult to incorporate absolutism into a legal theory (generally speaking), as 'absolutism's defining feature is to be a political system where the ruler is ultimately not bound by human law'. In addition, Gentili's understanding of the concept of sovereignty was at odds with the realities of Italy that had inspired the Italian late-medieval doctrines he was now relying upon. Indeed, in addition to the important constraints placed by law on public authorities in that context, these doctrines 'took into account the-to some degree - concurrent political authorities of the Emperor, of the pope, and of a regional ruler or city-state'. Wijffels, 'From Perugia to Oxford' 2008 (n. 11), 63-4. 